in addition to those mentioned in my paper read before the Royal Society, will, I hope, justify me in having advanced a theory of magnetism which I believe in every portion allows at least experimental evidences of its probable truth.

\section{THE REDE LECTURE}

THE following abstract report of Prof. Huxley's Rede Lecture given on Tuesday week in the Cambridge Senate House, to a crowded audience, has been revised, to the extent of removing any errors of importance, by the author. We understand that a full report of the lecture will shortly be published in a separate form.

Professor Huxley said he had undertaken to treat in the course of such time as custom and the patience of his audience might permit, on a very great subject, no less a subject than the origin of all those forms of animal life which at present existed. It had behoved him to restrict what he might lay before them to those considerations which were absolutely essential for his purpose, and he should endeavour to lay before them facts of such an order as appeared to him to be of most importance in reference to his argument. Although he might fail to put those facts before them as clearly as they presented themselves to his own mind, the reasonings which might be based upon them were of so simple an order that he should consider his task performed if he gave them a tolerably clear conception of what those facts were, for he did not think it was the business of a man of science to use the arts of rhetoric or endeavour to procure persuasion. His sole business was to place the facts before those whom he wished to teach, and to leave it to their reason to form such judgment upon those facts as they might think fit. In the present case he should point out to them what judgments such facts had forced upon his mind, but he must leave it entirely to their responsibility to say what judgment they might constrain them to give in their case. They miyht assume this position at tarting, that, whatever in such a matter was true for one animal, was true for the infinite series of the whole animal world; and as he was extremely anxious to avoio everything speculative, everything that could not be directly led back to the matters of fact upon which it was based, he proposed to select one animal particularly, and to put before them facts and arguments by the help of which they might form some probable conclu:ion as to the origin of that object. He took it for granted that, if the evidence inclined towards a particular conclusion in the case of that animal, they might assume that it would incline in the same direction with regard to all. He had no doubt that a great many of his audience were familiar at any rate with the shell of the animal about which he was going to speak, namely, that of the pearly nautilus, from which, or parts of which, very beautiful ornaments were fabricated. At the present time the nautilus inhabited the warmer parts of the Indian and Pacific Oceans, living at considerable depths and preying upon the hard shelled crustaceans and mollusks that crept along the bottom, and which it found in its way. For that end it was provided with a very curious beak, shaped like that of a farrot, but with each portion covered with a hard calcareous deposit, and which enabled it to be an efficient instrument for crushing its prey. If he were to touch upon the morphological problem which here presented itself, he could occupy far more time than they had at their disposal with the consideration of a multitude of interesting peculiarities which the nautilus presented, for it was one of those forms which at present stood almost isolated and alone in the animal world, separated by a wide gulf from its nearest allie:, those animals which they knew as squids and cuttle-fishes. It held the middle place between sea-snails and the group of the cuttle-fishes. It wonld be, however, entirely out of place at present, and a purposeless waste of time if he were to touch upon any peculiarities except those which would be needed during his further argument. The only points to which he would direct their attention for that purpose were the facts which related to the structure of the shell. There was a diagram beside him showing a part of the nautilus shell in section, but he thought it possible that he could make the matter clearer by roughly sketching on the board the main points as he went on.-Prof. Huxley here dessribed, with the aid of diagrams, preserved specimens, and models, the complicated structure of the shells of the pearly nautilus, or Nautilus pompilius. The animal itself was contained in the spacious chamber in the outer part of the shell, which was divided from the rest of the shell by a par- tition. The rest of the shell resembled a long cone closely coiled up, and divided by partitions at regular intervals into other chambers, which succetded one another, and in the full-grown animal were full of air. From the hinder part of the animal's body a long tube, the siphuncle, was carried backwards through the whole of the shell, and as it completely filled up the openings in the partitions through which it passed there was no communication between one chamber and another. The first point to be considered was as to what was the origin of the particular nautilus in the bottle before him. Happily there was no dispute upon that point. The female nautilus contained eggs exactly as the hen did. These eggs were small masses of protoplasmic matter, each containing a nucleus in its centre, which was all that was essential. They knew that that pearly nautilus with all its complicated organism, and fitted with the complicated shell he had described, did, in some way or other, proceed from that relatively structureless body which they called the egg or the ovum. As fate would have it, up to the present they had known nothing from direct observation of the process by which that particular animal was produced from this microscopic particle. But they had so large a knowledge of the process in other animals of every description that there was no doubt whatever as to the nature of the process, which he would try to describe to them as briefly as possible, by reference to the process which took place in the case of the domestic hen. Neither by the highest powers of the microscope, nor by other means of investigation which they had. at present, could they trace anything in the slightest degree resembling either the chick, which under certain circumstances proceeded from that egg, or the tissues of the chick. There was, however, one spot on the yolk of the egg, a little careful observation of which would show a clear space, which might be a fifth of an inch in diameter. It was very well known by the name of the cicatricula, or little scar. He would suppose that twenty-one eggs were placed together under the hen. If they took one egg day by day and examined it they would know what took place as if they had watched continuously, for what happened in any one egg happened also in the others. That was a process-the wonder of which he must confess never staled in his mind-by which the chick was gradually fashioned out of that transparent rudiment. They saw it make its appearance in the first place on the surface of the yolk, and to the naked eye it looked like a white streak. That white streak gradually assumed the appearance of a sort of elongated body, and that body shaped itself so that it could be seen that it was going to be an animal of some kind, it having a large head, and the rudiments of eyes and vertebræ. On the fifth day they could clearly see what they were going to have. Gradually, step by step, and moment by moment, new differences made their appearance from the original foundation, and until many days before hatching there was an unmistakable bird, and at the twenty. first day there emerged from the shell an animal endowed with all a bird's capacities and structures. That process was the process of development. If they inquired into the nature of the cicatricula, they would find that that was merely a double layer of minute nucleated cells. They would find that that resulted from the splitting up of a protoplasmic mass that had been there before. They could trace the process back into the body of the hen until they came down to a simple nucleated cell, so that it was a matter capable of demon tration that in that nucleated cel which formed a part of the egg organ of the hen-in that particle of, for morphological purposes, structureless jelly, were the same characteristics which were possessed by the very lowest forms of animal life which were known. They knew that in that particle resided a potentiality, capable of developing itself through the stages he had roughly indicated, until it became not only a machine of the highest order from a physiological point of view, but a very remarkable work of art. That particle of protoplasmic matter did that in virtue of the posers inherent in its material nature. That was the point he wished to put before them as clearly and definitely as he could, because it would be fundamental in all further discussion. For it was to the process he had briefly described that the great discoverers of the last two centuries applied the name of "evolution." Singularly enough the persons who fir:t used that name did not use it in that sense in which it was universally used now, becau e they were under a mistake as to the exact nature of the process. But the whole conception of evolution was now based upon ascertained facts, showing the process of development of the most complicated animal out of a relatively structureless particle, which had no higher organisation than that of the 
lowest animal they knew, a process which progressed step by step by means of the gcadual addition of small differences, until the animal attained its perfect form. That was what was meant by the process of evolution. At this point he thought it might be desirable that he should deal wi'h what he might speak of as the a priori objections to the doctrines of evolution. He had had opportunitie; of making extensive acquaintance with those objections during the past twenty years or so. He divided them into three categories: ( 1 ) That evolution was impossible; (2) that it was immoral ; and (3) that it was oppo ied to the argument of design. Now that was a very heavy indictment, but he thought they must plead "not guilty" upon all three counts. It required no great amount of reasoning to convince one that that which happened could not be impossible; that that which happened thousand: and millions of times every hour and every minute in this world as it now was, under certain conditions, could not be held without further evidence to be impossible under somewhat different conditions. Secondly, with regard to the question of morality. $\mathrm{He}$ had never understood that argument, and had always been disposed to reply that the morality which opposed itself to truth committed suicide. With regard to the argument of design he would not discuss that point himself, but would beg them to listen for a moment to words that would carry far more weight than any of his own could carry on that topic:- "The philosopher beholds with astonishment the production of things around him. Unconscious particles of matter take their stations and severally range themselves in an order so as to become collectively plants or animals, i.e. organised bodies with parts bearing strict and evident relation to one another and to the utility of the whole; and it should seem that these particles could not move in any other way than they do, for they testify not the smallest sign of choice, or liberty, or discretion. There may be particular intelligent beings guiding their motions in each case, or they may be the results of trains of mechanical disp ssitions fixe 1 beforehand by intelligence or appointment and kept in action by a power at the centre." They might imagine, and not unreasonably, that those were the words of some ultra-evolntionist of the present day who desired to set himself right with the argument from design; but they were not so. They were more than eighty years old, and they were contained in the 23rd chapter of a book which was very much talked about, but, he was afraid, very little read, namely, the "Natural Theology" of Archdeacon Paley. When he was a boy that book was a ve y great favourite of his, partly for its own merits, and partly because it was one of the few books he was allowed to read on Sundays. He found it much more entertaining than mo it of the books included in that categ ory. But from what had been since said of the Atheistic tendencies of the doctrine of evolution he began to think that he stood before them a miserable example of the manner in which a man's mind might be poisoned by early instruction, and that his incapacity to understand the force of the arguments against evolution arose from the circumstance that in his early childhood he was indoctrinated with the reasonings of a great divine of the Church.-Professor Hux!ey now proceeded to co ssider the next point, the coming into existence of the naitilus species in contradistinction from the origin of a particular nautilus as an individual. He showed that, according to all the evidence that could be gathered, there was every reason to believe the forms of animal life five thousand ye rrs ago were practically the same as they were now. If there were no other means of knowing anything absut the history of animal life, undoubtedly this experience, resting up in a duration of five thousand years, would have furnished an apparently sufficient basis for a generalisation, tending to the conclusion that the forms of animal life had not changed during that period. Not only had that generalisation been made, but it had been concluded that the forms of animal life were unchangeable, a totally different proposition, the validity of which rested, among other things, on the proportion between our actual experience, supposing it to extend over that time, and our passible experience of theduration of life on the globe. It would, he thought, be absolutely impossible for any of them, however good their vision, to say from actual observation of the hour hand of a watch for four seconds that it had moved during that interval, and in point of fact the space over which it would move was so minute as to be indiscernible, even through a magnifying glass. Yet they knew very well that it had moved, and if they watched it for four or five minutes, the evidence of its movement vould be perfectly obvious, even to the naked eye. They would observe, therefore, that a period of observation which extended over the nine-hundredth part of an hour, would give them no conception from which it would be possible to draw a conclusion as to what had happened during the total period. Now geologists told them that the whole depth and extent of the fussiliferous rocks, which composed a considerable portion of the earth's crust, repre:ented a period of time at least one thousand times as great as the historical period. That was a point upon which there could be no ruom for hesitation. Hence it followed that when they acquainted themselves with the succession of animal forms which were embedded at different depths in the earth's crust, they did exactly what the observer of a watch did when he kept his eyes fixed on it, not for four seconds but for an hour, in which latter case the movement was not only conspicuous, but such as commonly served to indicate the lapse of time. If that analogy held good, the slow procession of events which might be absolutely indiscernible in the course of 5,000 years, would become obvious and plain when the period of observation was extended to a thousand times that period. And that was exactly what happened, for if they went back in the series of stratified rocks they found the genus nautilus, which in the present day was represented by one or two species, represented in the long period of its history by many other species. As far back as the Upper Silurian formation the genus nautilus was represented by an abundant number of shells fabricated by animals having all the essential peculiarities which he had described. In the geological specimens before him, and which were taken from the rich collection in the Woodwardian Museum, there were forms of nautili which no one doubted were to all intents and purposes the same in their general structure as the pearly nautilus of the present day, although they were at least $5,000,000$ years old. Now came the main question: were those nautili whose history extended back through such a prodigious range of time identical in character with the modern species? So far as he knew there was nothin in the nature of things to show why a succession of generations which remained unchanged through 5,000 years should not remain so for 50,000 or $50,000,005$ years. The facts, ho: $\mathrm{x}$ ever, showed that there had been rather more than too distinct species of nautilus, each having as good a title to be called a species as Nautilus pompilius itself. No one of these species had endured for more than a portion of the duration of the whole genus, and many species had existed contemporaneously, those species, however, except perhaps two, were now extinct, so that now they were brought face to face with the heart of the question: by what hypothesi; could they account for those phenomena? They were driven into hypothesis of some kind or other, because it was impossible to have any evidence of contemporary witnesses of facts which went so far back into the past. So far as he knew there were only two possible alternative hypotheses by which they could pretend to account for those facts. One of these hypotheses was what he ventured to call the hypothesis of construction. That hypothe is was that every one of those species was put together. It was making a needless difficulty to supposs that each species came out of nothing, because they knew that the body of the nautilus was made up of materials which were familiar to them in an inorganic state on the earth's surface"; so that by the hypothesis of construction some agency had put together those materials a hundred times or so during the period that had elapsed from the formation of the Silurian rocks to the present day, as an artist constructed his u ork, or as a mechanician put together the parts of his machine. That was one hypothesis. For his part, he had not a word to say a priori against the pos sibility of that hypothesis. It was certainly conceivable and therefore, according to Hume's maxim, it was possible. But they must bring it, like all other hypotheses, to the test of facts and inquire how far it stood that test. He thought the hypothe is of construction presented two large and almost in superable difficultie:. The one was that it was absolutely opposed to everything that they had received traditionally concerning the origin of animal forms, and the second was that it was no less opposed to every doctrine which might reasonably be held upon ground of sane science. It stosd to rea on and common sense that they could have recourse only to those causes for the assumption of which there was some ground of analogy. The business of science would be extre:nely easy if for every even one were permitted to invent special causes having no analogy in nature. The difficulty of science was in tracing every event to those canses which were in present operation. That difficulty was being so constantly overcome that it had become a canon of 
physical science no less than it was a canon of historical science that speculation should confine itself to construing pirst events by the acralogy of those of the present time. 'I'the bypothesis of con structioniseemed to him unacceptatile, because it led them into contravention of tradition on the one side and into contraventiou of seientific logic on the other. The only other alternative hypothesis was that of evolution, wlich meatit that the different forms of animal life lrad not arisen independently of each other in the great sweep of past time, but that the one had proceeded from the other; and that that which had happenecl in the course of past ages had been analogous to that which touk place daily and hourly in the case of the individual, That was to say that just as at the present dxy in the course of individual development the lower and simple forms, in virtue of the properties which were inherent in them, yalssed step by sten by the establishnent of small successive wifferences into the higher and more complicated forms, so, in the case of pasi ayes, that which constituted the stock of the whole ancestry had advanced grade by fracle and step by step until it had attnined the degree of complexity which tas seeu at the present day. No objection coukd be brought against this hypothesis on the ground of analchy, because in pufting it forward they were not bringing in itny hind of tausa. tion which was not abuudantly operative $a t$ the present time. The question was whether the bistory of the globe in gast lime coincided with this hypothesis, and to that point he wenld next address binself, What slid they fond if they considered the whole series of these formes? Unugitestionalify, as he haxi said, nautili were fouml as las back as the (! prec Siturian aye. Before that time there were no nautili, but there were shelis of the Orthoscratide of which there were magriticcrst f xamplstes before niat-which rescmbled those of the nautili in that they were cilambered, siphoned, \&c., with the last chamber of sach a fise that it abysolly shelered thic boty of the amimal. Ho tbonght no one cruld douht that the crealues which liahuicaled these still earlier shells were substantially similay to the namtili, altbough their shells were straight, just as iz maulifws shelt would toe if it were pulled out from a belix into a cone. Thon came the forms know't as the cyrtoceras, which were slightly curvel. A long with these they bad the sther forms which were on the table, and in which the shell began to yrow spiral. Jhe rext that came werc forms of rautilas, which differel from the mativas of ta.day in that the septa were like watcli.glasses, and that the whorls did not overlay one anvtier. In the next series, belonging to the later paleozoic strata, the shell vas closely coiled and the stoda began to be a litte vavy, and the whorls began to owerlap oue alkather, And this process was continued in later formas, down to that of the present day. Looking lyoadly at tike wajn changes which the naxlilus stoek tridervent, tbanges jnsaliel with those which were followed by the individant nautifus in lie course of is development, he considered that there coukl the mistotbt tist ibey were justifed in the laypollesis that the caures at worls zoct the same in toth crses, and that the inberent facully, ox pout: or whatever else it might be called, which deterintned thesuccossive changes of the jautious alter it had been hatched, laal been operative throughent the whole continuous series of cxictence of the genus from its earliest appearances in the hatcr Silurian tack.s up to the puesent day. Wlat the whole question, in whatever way it might be put, came to, was this : Successive generations of animals were so many cycles of evolution that succeeded one another. Within the bisturical period, there was no doutst that, speaking roughly, those : ucceecling cycles biul been iclentical, that was to sny, without discernible difference. But when the period of observation became proportional to the slow rate of cliange they found, so to speak, that the hour hand had mover; for, in the succes sive cycles of evolution which has orcupied the whole period, successive cycles had diflered fron one anotber to a slight extent. If they might issume / hat, then the whinle of the phenomena of palocuntulory woukd fall into arfler and inteJligibility. If not, they hal to adopt in lypothesis which, as he had pointed out, had no support in tradition, and which was absolutely contradicted by every sound canon of scientific researcl). This was his case for evolution, which he rested wholly upon arguments of the kind he barl adduced. From the lime when he first read Charles Darwin's "Origin of Specics," now some twenty-four years ago, his mind lad fixed itself upon the tenth chapter of that book, which treated of the sticcession uf forms in geological times, for it appeured to him that that was the key of the position; that if the stoctrite of evolution was correct, the facts of palsontolugy, as zoon as they became sthficiently known, must bear it out ankt verify it in crery parsicular.
On the other hand, he believed that, if the facts of palacontology or the historical facts of life on the globe were against evolution, then inll the rest of tle argumentation in its favour wonk be valn aud enpty, because the dificulty of adopting it would be in that cuse ahsolutely insuperable. Ife would venture to repeat that the occurrence of evolution was a question of history. He did mit know whelher Sir Henry Maine was not more competent to spenk on that foint than he was. It was a question as to whather they would interpret the fincts of animated nature scientifically, or whether they would open the door to every description of byporhetical vagrary, [Ie came to the conclusion that that was a puine worth testing in every possible way, and for some twenty yeats he had given what leisuce he bad been able to beg, borrow, or sometimes steal, to the investigation of these questions. He bud enclenvoured to ascertain for himself how the doctrine of evolution nitted with the facts of palieuntologywith regard to the higher vortebrated animals, and with regarkl to the chief varieties of invertebrate animnls, and all he could tell them was that the farther his awn investigntions bad gone, tlse more conplete bad appeared to the the coincidence between the facts of palantology and the requirements of the doctrime of evolution. The conclu. sirn hie liad come to $x$ as thar at whith every competent person whe had undertaken a similar irguiry bad artived, and if they woukl pay attention to the writings of such uen as fraudry, Kijtiwejer, Markh. Cope, and others, who had added nuterials upen whicts to form a judgenent such as wete not dreame of when inatwin fiest wrote, buey would find titat they all without hesitation artached themselves to the doctrine of evolution as the only licy to lise enigara. In deciding the issue betwecm be two by collaese s, serions inquires world not trouble themselves aixutat any collateral points as to the how and the $u$ hy, or as io any of the subrordinate points at isuc. Yle thought he was entitled to eritucat those who by their calling or by their posinan in society, or ly the fact that they possessed any inAnterce, migbt be led to express an opinion voon lihis matter, to lowk into the arguments which formed lhe foundation of the case for evolution. Happily, lat might address tirat recommendatiou to menthers of the Linivessity of Camluridge with a perfectly

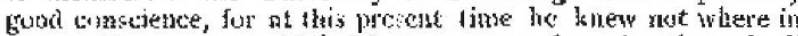
the world any one could fod belfer woans of passing thongl all inose preiminary studies nihich were essential to a comprehemsion 12f dyis great qutestion, or where any one could find pure amply displayed the means of terting lise arguments which he hal inisl before them. He ventured to say that the members of this Innversity werc withouk excuse if they gave opinions on this question of crolution withont having prepared themselves, by

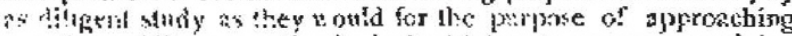
4uesticns of literary or theculogical cricicism, to express an opinion ijown it. These werc the coasiderations which he has wished to set hefore them that day. It would be understord that they woutil not sulliw: (o entable any one to form a jurjponent upon the doclsine of evolution, but he hoped ffat they had solfeced, brief find in ufficient as they were, to show that if judguent. on fhis question was to he wotk anything intellectually, if it was to be creditable to the mont sene of ilose whirs formed it, it would first be steserestry that the facts shutld te cicarly conoprchended, ank that the couclusion- - woutever it rojght be-chould be me which right deason would aduit night be justly and perfectly comesced with the lincts.

\section{UNIVERSTTY AND EDUCATIONAL INTE LI.JGENCE}

OxFoxn.-The teru that bas jnst concluded has been chiefly nuticenble for the intcrest drawn towards Oriental studies in the University by the buileling of the sew Indian Institute. The visit of the Plince of Wales to the Chanceilor of the University sitved to draw national altention to the nork which Oxford, and esperially Halliol College, has uncertaken in respect to the thaning of the selected candidates for the Indian Civil Service. In spite of the failure of the late attermpt to induce the University to rela $x$ its tule vequiring three gears' residence as a qualificution lor a P. A, depree in tie casc of the Indian Civil Servants, n consicleruble proportion of the selected eardiclates come into residence at the University; Balliol, by providing teachers and tutors in Oriental subjects, attracts by far the greatert number.

With she exception of two debates there has becn little excitement during the term in the Convocation House. The two gustions that touted gencinl interest werc, first, the proposal that 